\title{
Cow characteristics and their association with production performance with different dry period lengths
}

\author{
W. Steeneveld, ${ }^{* 1}$ A. T. M. van Knegsel,† G. J. Remmelink,‡ B. Kemp,† J. C. M. Vernooij,§and H. Hogeveen*§ \\ ${ }^{*}$ Chair group Business Economics, Wageningen University, Hollandseweg 1, 6706 KN Wageningen, the Netherlands \\ †Adaptation Physiology Group, Department of Animal Sciences, Wageningen University, PO Box 338, 6700 AH Wageningen, the Netherlands \\ fLivestock Research, Wageningen University and Research Centre, PO Box 65, 8200 AB Lelystad, the Netherlands \\ §Department of Farm Animal Health, Faculty of Veterinary Medicine, Utrecht University, Yalelaan 7, $3584 \mathrm{CL}$ Utrecht, the Netherlands
}

\begin{abstract}
Shortening or omitting the dry period (DP) has been proposed as a management strategy to improve energy balance of dairy cows in early lactation. Both shortening and complete omission of the DP reduces milk production in the subsequent lactation compared with a conventional DP length of $60 \mathrm{~d}$. Some cows have less milk production loss than other cows after applying no DP or a short DP. The aim of this study is to evaluate which cow characteristics are associated with the amount of milk production losses following no DP or a short DP (30 d). Daily production information from the lactation before and after the DP was available from 161 dairy cows (54 cows with a 0-d DP, 51 cows with a $30-d$ DP, and 56 cows with a 60 -d DP) from a research herd. Daily production (milk, fat, and protein) until 305 d in milk was estimated for all cows. Subsequently, total fat- and protein-corrected milk yield from $60 \mathrm{~d}$ before the expected calving date until $305 \mathrm{~d}$ in the following lactation $\left(\mathrm{FPCM}_{\text {total }}\right)$ was estimated. A statistical analysis was performed to evaluate which cow characteristics were associated with limited or no production losses following no DP or a short DP, compared with a conventional DP length of $60 \mathrm{~d}$. Average $\mathrm{FPCM}_{\text {total }}$ was $9,341,10,499$, and $10,795 \mathrm{~kg}$ for cows with no DP, a 30-d DP, and a 60-d DP, respectively. The cow characteristics parity, daily milk production at $12 \mathrm{wk}$ before the expected calving date, and reduction in daily milk production between 16 and 12 wk before the expected calving date were associated with production loss due to a short $(30 \mathrm{~d})$ or no DP. Compared with $60 \mathrm{~d}$ DP, multiparous cows had less production loss $(987 \mathrm{~kg})$ following no DP than primiparous cows $(2,132 \mathrm{~kg})$. The difference in $\mathrm{FPCM}_{\text {total }}$ between the 3 DP groups was largest for cows with a low milk production (e.g., $10 \mathrm{~kg} / \mathrm{d}$ ) at $12 \mathrm{wk}$ before the expected calving date. The greater the reduction in milk production
\end{abstract}

Received December 20, 2013.

Accepted April 30, 2014.

${ }^{1}$ Corresponding author: wilma.steeneveld@wur.nl between 16 and 12 wk before the expected calving date, the larger the difference in $\mathrm{FPCM}_{\text {total }}$ between the $3 \mathrm{DP}$ groups. The difference in $\mathrm{FPCM}_{\text {total }}$ between cows with no DP and $60 \mathrm{~d}$ DP at a reduction in milk production between 16 and 12 wk of $10 \%$ was $665 \mathrm{~kg}$, whereas this difference was $1,138 \mathrm{~kg}$ at a reduction of $70 \%$. The cow characteristics found can be used to select cows for specific DP lengths in a decision-support model to support the farmer on the economic optimal DP length for each individual cow. Output of such a decision-support model can be, for instance, to advise a 30-d DP for multiparous cows with high milk production (e.g., 25 $\mathrm{kg} / \mathrm{d}$ ) at $12 \mathrm{wk}$ before the expected calving date.

Key words: dry period length, individual cow variation, milk yield, continuous milking

\section{INTRODUCTION}

High-producing dairy cows experience a negative energy balance following parturition. This negative energy balance results from a fast increase in energy requirements for milk production while feed intake capacity in early lactation is limited. A negative energy balance in early lactation is related to mobilization of body reserves and loss of BW, an increase in incidence of metabolic disorders (Grummer, 1993), infectious diseases (Collard et al., 2000), and reduced fertility (Butler, 2003). Shortening the dry period (DP) has been proposed as a management strategy to improve energy balance of dairy cows in early lactation (Grummer and Rastani, 2004). Also applying no DP has been reported to result in an improved energy balance and metabolic status (Rastani et al., 2005; Schlamberger et al., 2010).

Shortening $(30 \mathrm{~d})$ or omitting the DP $(0 \mathrm{~d})$ results, however, also in lower milk production in the next lactation. In a meta-analysis including 22 studies, cows with a short DP produced $1.4 \mathrm{~kg} / \mathrm{d}$ less milk than cows with a conventional DP, with an average milk loss of $4.5 \%$ in the next lactation (van Knegsel et al., 2013). When the DP was omitted, cows produced $5.9 \mathrm{~kg} / \mathrm{d}$ less milk than cows with a conventional DP, with an average milk loss of $19.1 \%$. Across studies, milk protein 
percentage increased postpartum, on average, by $0.06 \%$ when the DP was shortened and by $0.25 \%$ when the DP was omitted. Across studies, milk fat percentage was not affected by DP length (van Knegsel et al., 2013). Some studies did take the additional milk production before calving into account (Rastani et al., 2005; Mantovani et al., 2010; Schlamberger et al., 2010), but also that resulted in an overall lower milk production.

Some cows have less milk production loss than other cows after applying no DP or a short DP. Especially the effect of parity on milk production after a short or omitted DP, compared with a conventional DP, is mentioned in several studies. Pezeshki et al. (2007) reported that the reduction in milk production after a short DP was larger for primiparous cows compared with multiparous cows. Both Annen et al. (2004) and Santschi et al. (2011a) reported a reduction in milk yield for primiparous cows with a short DP or no DP but not for multiparous cows.

The reported parity effect would imply that selecting specifically multiparous cows for no or a short DP will result in limited or no milk production losses. Moreover, besides parity, probably also other cow characteristics can be related to the production response of dairy cows to a short or no DP. It could be expected that knowledge on cow characteristics that determine the production response of dairy cows to shorter DP could be applied to optimize dairy cow management and result in economic benefits for applying an individual-cow approach with different preplanned DP lengths. Preferably, these cow characteristics would be available at the moment a farmer needs to decide about the DP length of the cow (e.g., 8-12 wk before the expected calving date). For instance, production level (milk, fat, and protein), expected calving interval, and BCS could probably be cow characteristics that could be used to select cows for no DP or a short DP resulting in limited or no milk production losses. Also, Klusmeyer et al. (2009) mentioned that selecting high-producing cows for a 32-d DP resulted in substantially more total milk. Milk components, however, were not taken into account in that calculation (Klusmeyer et al., 2009). In contrast, previously, no interaction was found among preplanned DP length (4, 7, or $10 \mathrm{wk})$ and parity, days open in previous lactation, previous milk yield, and health status and milk production in the subsequent lactation (Sørensen and Enevoldsen, 1991). Their study used data from 1989 and 1990 and did not include cows with no DP or the additional milk produced before calving.

The aim of the current study was to evaluate which cow characteristics are associated with milk production losses following no DP or a short DP (30 d) compared with a conventional DP $(60 \mathrm{~d})$.

\section{MATERIALS AND METHODS}

\section{Experimental Design, Animals, and Housing}

The Institutional Animal Care and Use Committee of Wageningen University and Research Centre (WUR, Lelystad, the Netherlands) approved the experimental protocol. Holstein-Friesian dairy cows $(\mathrm{n}=168)$ were selected from the Dairy Campus Research dairy herd (WUR Livestock Research) for the experiment on the effect of DP length $(0,30$, and $60 \mathrm{~d})$ on production. These selected cows were served by a Holstein sire, had an expected calving interval less than $490 \mathrm{~d}$, had a daily milk production at $90 \mathrm{~d}$ before the expected calving date of more than $16 \mathrm{~kg} / \mathrm{d}$, and had no mastitis or high SCC $(>250,000$ cells $/ \mathrm{mL})$ at the 2 test days before drying off. The experiment started with 60 primiparous cows and 108 multiparous cows. Cows were blocked for parity (primiparous or multiparous), expected calving date, milk production in the previous lactation, and BCS and randomly assigned to length of DP $(0,30$, or $60 \mathrm{~d}$ dry) and early lactation ration (glucogenic or lipogenic), resulting in a $3 \times 2$ factorial design. One cow (30 d dry) was excluded from the experiment because of a mistake in the drying-off protocol. In principle, the aim was to continuously milk all the cows. In the beginning of the experiment, however, some ( $\mathrm{n}=$ $10 ; 19 \%$ of cows in the 0 -d-dry group) cows dried off themselves. These cows were not milked anymore. The treatment (diet and group) of these cows stayed the same as the cows in the 0-d-dry group, which were still milked. Cows were housed in a freestall with slatted floor and cubicles. At the day of calving, cows went to a stable with straw. During lactation, cows were milked twice daily $(0500$ and $1630 \mathrm{~h})$. The drying-off protocol for cows with the 30- and 60-d DP consisted of a transition to the far-off ration at d 7 before drying off, and milking once daily at d 4 before drying off cows. At drying off, cows were treated with an intramammary antibiotic (Supermastidol; Virbac Animal Health, Barneveld, the Netherlands). Milk yield was recorded daily from $16 \mathrm{wk}$ before the expected calving date until the end of the following lactation. Predicted or realized 305-d milk production from the lactation before the DP were obtained from the Dutch national milk recording system (CRV, Arnhem, the Netherlands). Milk samples for fat and protein analysis (ISO 9622; Qlip NV, Zutphen, the Netherlands) were collected 4 times per week (Tuesday afternoon, Wednesday morning, Thursday afternoon, and Friday morning). Body condition was scored (5-point scale, where $1=$ thin and $5=$ obese; Wildman et al., 1982) every 4 wk by the same experienced person. More details about the experimental design were reported earlier (van Knegsel et al., 2014). 


\section{Rations}

Details on ration composition and feeding strategy are described in van Knegsel et al. (2014). In short, prepartum, dry cows received a dry cow ration and lactating cows received a lactating cow ration supporting $25 \mathrm{~kg}$ of milk. From $10 \mathrm{~d}$ prepartum until 100 DIM, all cows were fed one of the experimental concentrates (lipogenic or glucogenic) and when lactating, cows received in the milking parlor $1 \mathrm{~kg} / \mathrm{d}$ of standard lactation concentrate. After 100 DIM, experimental concentrates were replaced by standard lactation concentrate for all cows. Forage composition consisted prepartum of grass silage, corn silage, wheat straw, and a protein source (rapeseed meal or soybean meal) in a ratio of 39:25:25:11 (DM basis). Postpartum until 211 DIM, forage consisted of grass silage, corn silage, straw, and a protein source in a ratio 51:34:2:13 (DM basis). From 211 until 305 DIM, the ration consisted of lactation concentrate, grass silage, corn silage, straw, and a protein source in a ratio of 5:74:9:4:8 (DM basis).

\section{Data Editing}

Originally, the data consisted of 167 cows. Six cows were excluded from the data set because they were culled before 100 DIM. The final data set included 161 cows (54 cows with $0 \mathrm{~d}$ dry, 51 cows with $30 \mathrm{~d}$ dry, and 56 cows with $60 \mathrm{~d}$ dry). From all cows, daily milk yields were available from the lactation before and after the application of different DP lengths. In total, 101 of the 161 cows reached 305 DIM and 60 did not reach 305 DIM because of health problems (0-d DP: $\mathrm{n}=6$; 30-d DP: $\mathrm{n}=1 ; 60-\mathrm{d}$ DP: $\mathrm{n}=1)$, too low production $(0-\mathrm{d}$ DP: $\mathrm{n}=1$ ), or dried off before d 305 because of an early pregnancy $(0-\mathrm{d}$ DP: $\mathrm{n}=15 ; 30-\mathrm{d}$ DP: $\mathrm{n}=17 ; 60-\mathrm{d}$ DP: $\mathrm{n}=19$ ). This means that the $305-\mathrm{d}$ milk production could not be calculated for all cows from the daily measurements.

\section{Statistical Analyses}

Analysis 1: Estimating 305-d Production. Not all cows reached 305 DIM following the different DP lengths. Therefore, daily production (milk, fat, and protein; all in $\mathrm{kg} / \mathrm{d}$ ) until 305 DIM was estimated for all cows using PROC MIXED of SAS (version 9.2; SAS Institute Inc., Cary, NC). The shape of the lactation curve was modeled using the Wilmink model and included DIM and the factor exponential ${ }^{-0.05 D I M}$ (Wilmink, 1987). The model also included parity ( 2 or $\geq 3$ ), DP length (0,30, and $60 \mathrm{~d}$ dry), and calving season (January-March, April-June, July-September, and October-December) as fixed effects. An autoregressive covariance structure accounting for repeated days with yields (coded 1 to 305) within a lactation of a cow was incorporated. All variables were analyzed using a backward stepwise procedure. Only variables at $P \leq$ 0.05 in the Wald test were retained in the model. Calving season was forced into the model. The initial model was as follows:

$$
\begin{aligned}
& y_{i j k}=\beta_{0}+\beta_{1, m} \text { Parity }+\beta_{2} \mathrm{DIM}_{i j k}+\beta_{3} \exp ^{-0.05 \mathrm{DIM}_{i j k}} \\
& +\beta_{4, n} \text { Season }+\beta_{5, o} \mathrm{DP}+\rho \varepsilon_{i j k},
\end{aligned}
$$

where $y_{i j k}$ is the yield of cow $i$ in DP category $j$ on day $k, \beta_{1, m}$ is the effect of the $m$ th parity, $\beta_{2}$ is the effect of DIM, $\beta_{3}$ is the effect of Wilmink's correction, $\beta_{4, n}$ is the effect of the $n$th calving season, and $\beta_{5, o}$ is the effect of the oth DP category $(0,30$, and $60 \mathrm{~d}$ dry $)$. The term $\rho \varepsilon_{i j k}$ is an error term consisting of 2 components: $\rho$ is the within-cow correlation (assuming autocorrelation) and $\varepsilon_{i j k}$ is the random error term. Six interaction terms were also included, and these included parity with DP category, Wilmink's correction with DP category, DIM with DP category, calving season with DIM, parity with DIM, and Wilmink's correction with parity (not shown in the model). Estimated intercepts and regression coefficients were used for fitting the lactation curve until 305 DIM for each cow in the data set. For each cow, the daily production (milk, fat, and protein; in $\mathrm{kg} / \mathrm{d}$ ) is summed up until 305 DIM. Goodness of fit of the models was assessed by judging the residuals. The residuals were plotted against the fitted values and judged for normality and peculiarities (Dohoo et al., 2009). The residuals were normally distributed and residuals were similarly distributed between the DP groups.

Subsequently, the total fat- and protein-corrected milk (FPCM) yield from $60 \mathrm{~d}$ before the expected calving date until $305 \mathrm{~d}$ in the following lactation $\left(\right.$ FPCM $\left._{\text {total }}\right)$ was calculated for all cows with the following equations:

$$
\begin{gathered}
\text { FPCM }_{-60}=[0.337+(0.116 \times \text { average } 60-\mathrm{d} \text { fat } \%) \\
+(0.06 \times \text { average } 60-\mathrm{d} \text { protein } \%)] \\
\times 60-\mathrm{d} \text { milk production; } \\
\text { FPCM }_{305}=[0.337+(0.116 \times \text { average } 305-\mathrm{d} \text { fat } \%) \\
+(0.06 \times \text { average } 305 \text {-d protein } \%)] \\
\times 305 \text {-d milk production; } \\
\text { FPCM }_{\text {total }}=\text { FPCM }_{-60}+\text { FPCM }_{305},
\end{gathered}
$$

where the average $60-\mathrm{d}$ fat $\%$ and the average $60-\mathrm{d}$ protein $\%$ was calculated as the weighted average fat and 
protein percentage of the last $60 \mathrm{~d}$ before the expected calving date, respectively. The $60-\mathrm{d}$ milk production was the sum of the daily milk yields from $60 \mathrm{~d}$ before the expected calving date until the day of calving. The average 305-d fat $\%$ and average $305-\mathrm{d}$ protein $\%$ was calculated by dividing the 305-d fat and protein production by the 305-d milk production (all obtained with analysis 1).

Analysis 2: Determining Cow Characteristics that Influence Production Loss. A statistical analysis was performed to evaluate which cow characteristics were associated with limited or no production losses following no DP or a 30-d DP using a generalized linear model in SAS (PROC GLM). The dependent variable in the statistical analysis was the $\mathrm{FPCM}_{\text {total }}$. In the statistical analysis, the cow characteristics of the lactation before applying different DP lengths were defined as independent variables. The independent variables were expected calving interval, average daily milk production at $12 \mathrm{wk}$ before the expected calving date, average fat and protein production at $12 \mathrm{wk}$ before the expected calving date, 305-d milk production $(<9,000,9,000$ 10,000 , or $\geq 10,000 \mathrm{~kg}$ ) of the lactation before applying different DP lengths, and percentage reduction in milk production between 16 and $12 \mathrm{wk}$ before the expected calving date, $\mathrm{BCS}(\leq 2.5,2.5$ to 3 , or $>3)$ at $11,10,9$, and $8 \mathrm{wk}$ before the expected calving date and parity ( 1 or $\geq 2$ ). Expected calving season (January-March, April-June, July-September, and October-December) and ration (glucogenic or lipogenic) in early lactation were forced into the model. All variables were analyzed using a backward stepwise procedure. Only variables at $P \leq 0.05$ in the Wald test were retained in the model. The initial model was as follows:

$$
\begin{gathered}
y_{i j}=\beta_{0}+\beta_{1, k} \mathrm{DP}+\beta_{2, l} \text { Ration }+\beta_{3} \mathrm{CI}_{i j}+\beta_{4}{\text { Milk} 12_{i j}} \\
+\beta_{5} \text { FatProtein } 12_{i j}+\beta_{6, m} \text { Milk305 }+\beta_{7} \text { Reduction } \\
+\beta_{8, n} \mathrm{BCS}+\beta_{9, o} \text { Parity }+\beta_{10, p} \text { Season }+\varepsilon_{i j},
\end{gathered}
$$

where $y_{i j}$ is the $\mathrm{FPCM}_{\text {total }}$ of cow $i$ in DP category $j, \beta_{1, k}$ is the effect of the $k$ th DP category (0,30, or $60 \mathrm{~d}$ dry), $\beta_{2, l}$ is the effect of the $l$ th ration category, $\beta_{3}$ is the effect of the expected calving interval, $\beta_{4}$ is the effect of the milk production at $12 \mathrm{wk}$ before the expected calving date, $\beta_{5}$ is the effect of fat and protein production at 12 wk before the expected calving date, $\beta_{6, m}$ is the effect of the $m$ th category on the 305 - $\mathrm{d}$ milk production, $\beta_{7}$ is the effect of the reduction in milk production between 16 and 12 wk before the expected calving date, $\beta_{8, n}$ is the $n$th BCS category, $\beta_{9, o}$ is the effect of the oth parity, $\beta_{10, p}$ is the effect of the $p$ th expected calving season, and $\varepsilon_{i j}$ is the random error term. The following interaction terms were also included: parity with expected calving interval, parity with milk production at $12 \mathrm{wk}$ before the expected calving date, expected calving interval with milk production at $12 \mathrm{wk}$ before expected calving date, expected calving interval with reduction in milk production between 16 and 12 wk before expected calving date, and the interactions between each of the cow characteristics of the previous lactation with the DP length (not shown in the model).

\section{RESULTS}

The final data set included 54 cows with no DP, 51 cows with $30 \mathrm{~d}$ DP and 56 cows with $60 \mathrm{~d}$ DP. Actual days dry were $2 \pm 6.5,30 \pm 4.1$ and $61 \pm 5.9 \mathrm{~d}$ dry (Means $\pm \mathrm{SD}$ ) for cows with no DP, $30 \mathrm{~d}$ DP and $60 \mathrm{~d}$ $\mathrm{DP}$, respectively.

\section{Analysis 1: Estimating 305 d production}

For every cow the milk lactation curve until 305 DIM was fitted (Figure 1). Average $305 \mathrm{~d}$ milk production for cows with no DP, $30 \mathrm{~d}$ DP and $60 \mathrm{~d}$ DP was 7,685 $\mathrm{kg}, 9,101 \mathrm{~kg}$ and $9,753 \mathrm{~kg}$, respectively. Second parity cows had a $305 \mathrm{~d}$ milk production of $6,981 \mathrm{~kg}, 9,500$ $\mathrm{kg}$ or $9,793 \mathrm{~kg}$ for no, $30 \mathrm{~d}$, or $60 \mathrm{~d} \mathrm{DP}$, respectively. Multiparous cows had a 305 d milk production of 7,287 $\mathrm{kg}, 9,015 \mathrm{~kg}$ and $9,780 \mathrm{~kg}$ for no, $30 \mathrm{~d}$, or $60 \mathrm{~d} \mathrm{DP}$, respectively. Also lactation curves until 305 DIM are fitted for fat and protein production (Figure 2). Average $305 \mathrm{~d}$ fat production for cows with no DP, $30 \mathrm{~d}$ DP and $60 \mathrm{~d}$ DP was $336 \mathrm{~kg}, 413 \mathrm{~kg}$ and $425 \mathrm{~kg}$, respectively. Average 305 d protein production for cows with no DP, $30 \mathrm{~d}$ DP and $60 \mathrm{~d}$ DP was $285 \mathrm{~kg}, 333 \mathrm{~kg}$ and $347 \mathrm{~kg}$, respectively.

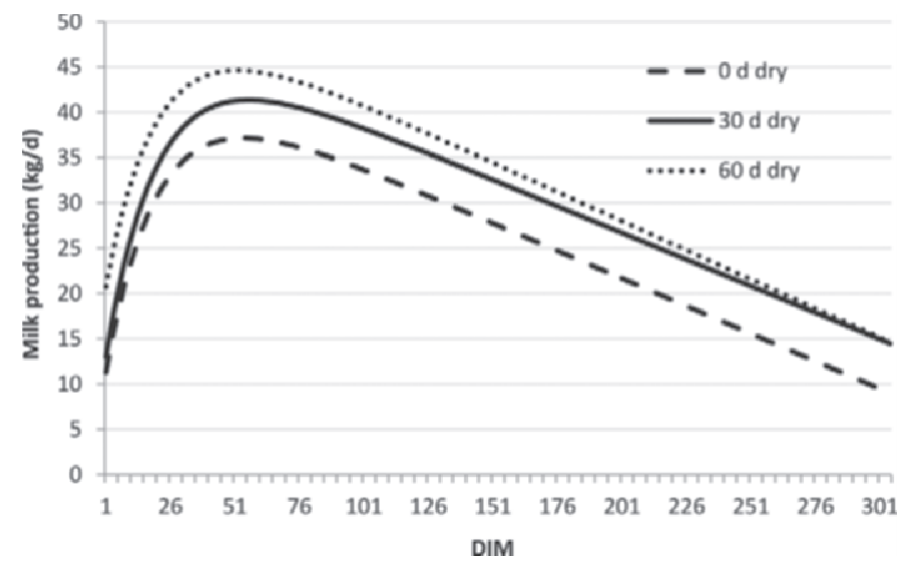

Figure 1. Estimated lactation curve (kg of milk/d) for $305 \mathrm{~d}$ subsequent to no dry period, a 30-d dry period, and a 60-d dry period. The curve shows the milk production of a group of cows in a single parity, in a single season, and across DIM. 

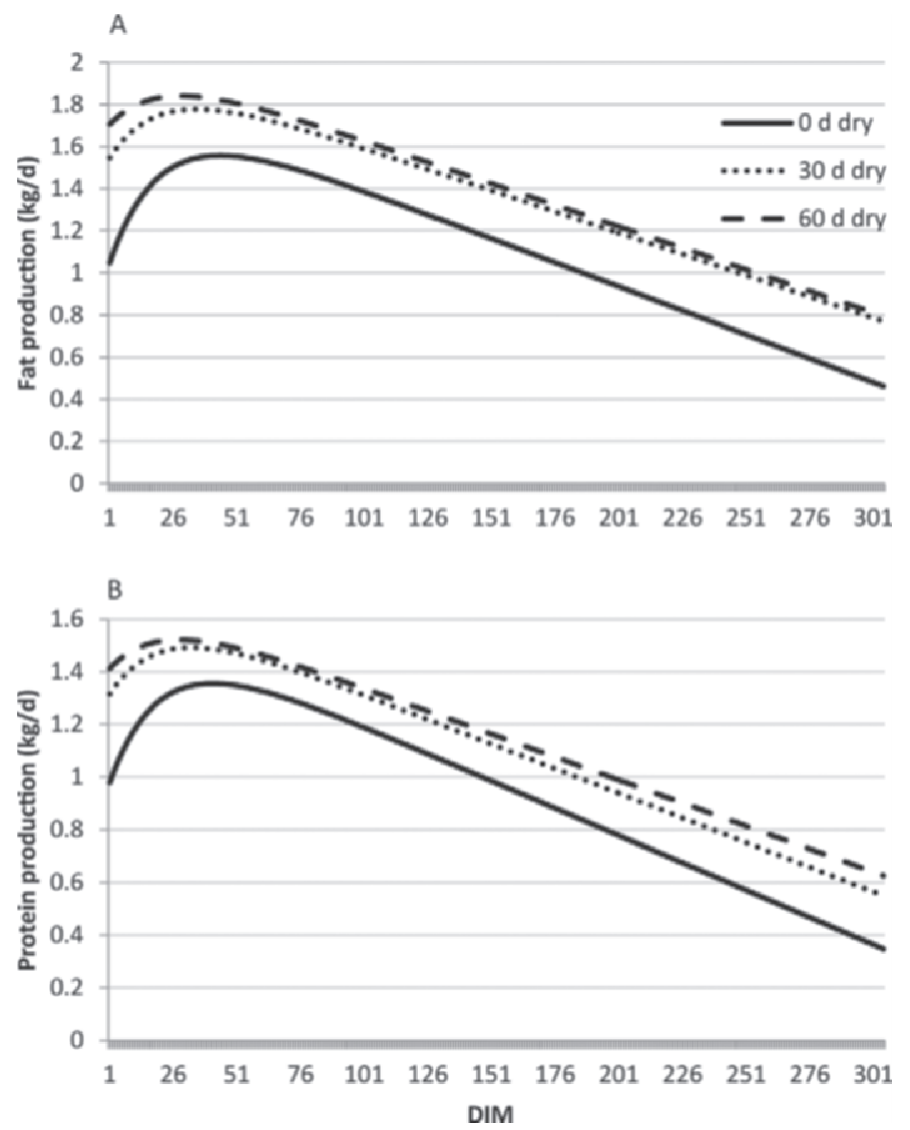

Figure 2. Estimated lactation curve for fat (A) and protein (B) production $(\mathrm{kg} / \mathrm{d})$ for $305 \mathrm{~d}$ subsequent to no dry period, a 30-d dry period, and a $60-\mathrm{d}$ dry period. The curve shows the milk production of a group of cows in a single parity, in a single season, and across DIM.
Subsequently, information from the fitted lactation curves for milk, fat and protein was used to calculate $\mathrm{FPCM}_{305}$ per cow (Table 1). Cows with $0 \mathrm{~d}$ DP or 30 d DP produced more milk precalving, but less postcalving, compared with cows with a $60 \mathrm{~d}$ DP. Average $\mathrm{FPCM}_{305}$ was $8,361 \mathrm{~kg}, 9,954 \mathrm{~kg}$ and $10,784 \mathrm{~kg}$ for cows with no DP, $30 \mathrm{~d} \mathrm{DP}$, or $60 \mathrm{~d} \mathrm{DP}$, respectively. Additional FPCM produced in the last $60 \mathrm{~d}$ before calving $\left(\mathrm{FPCM}_{-60}\right)$ was $980 \mathrm{~kg}$ and $545 \mathrm{~kg}$ for the cows with no DP and a $30 \mathrm{~d}$ DP, respectively. Average $\mathrm{FPCM}_{\text {total }}$ (and range) for the respective DP groups are 9,341 kg $(8,346$ to $10,746 \mathrm{~kg}), 10,499 \mathrm{~kg}(9,480$ to $11,553 \mathrm{~kg})$ and $10,795 \mathrm{~kg}(10,367$ to $11,700 \mathrm{~kg})$.

\section{Analysis 2: Determining Cow Characteristics that Influence Production Loss}

Cow characteristics of the lactation before drying off were similar for the different DP groups (Table 1). Pearson correlations were calculated between cow characteristics before application of the DP length and FP$\mathrm{CM}_{\text {total }}$ after different DP lengths, per DP length (Table 2 ). Daily milk production at $12 \mathrm{wk}$ before expected calving date $(\mathrm{r}=0.35)$, fat and protein production at 12 wk before expected calving date $(\mathrm{r}=0.35)$, and 305 -d milk production $(\mathrm{r}=0.41)$ were positively correlated $(P<0.05)$ with $\mathrm{FPCM}_{\text {total }}$ for cows with no DP, whereas nonsignificant correlations were found for cows with 30 - or 60-d DP. Parity was positively correlated $(\mathrm{r}=0.35 ; P<0.05)$ with $\mathrm{FPCM}_{\text {total }}$ for cows with no $\mathrm{DP}$, but was negatively correlated $(\mathrm{r}=-0.632$ and $\mathrm{r}=$ $-0.408 ; P<0.05)$ for cows with 30 - or $60-\mathrm{d}$ DP. Multiparous cows with no DP had a greater $\mathrm{FPCM}_{\text {total }}$ than primiparous cows with no DP. Multiparous cows with a

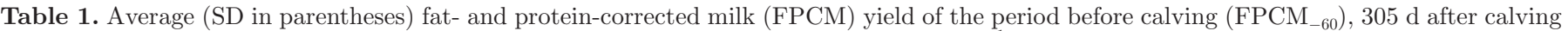
$\left(\mathrm{FPCM}_{305}\right)$, and total FPCM $\left(\mathrm{FPCM}_{\text {total }}\right)$ of cows with a dry period length of 0,30 , or $60 \mathrm{~d}^{1}$

\begin{tabular}{|c|c|c|c|}
\hline Item & \multicolumn{3}{|c|}{ Dry period length } \\
\hline $\mathrm{FPCM}_{-60}(\mathrm{~kg})$ & $980^{\mathrm{a}}(403)$ & $545^{\mathrm{b}}(177)$ & $11^{\mathrm{c}}(22)$ \\
\hline $\mathrm{FPCM}_{305}(\mathrm{~kg})$ & $8,361^{\mathrm{a}}(513)$ & $9,954^{\mathrm{b}}(472)$ & $10,784^{\mathrm{c}}(416)$ \\
\hline $\mathrm{FPCM}_{\text {total }}(\mathrm{kg})$ & $9,341^{\mathrm{a}}(600)$ & $10,499^{\mathrm{b}}(494)$ & $10,795^{\mathrm{c}}(416)$ \\
\hline Fat and protein production at 12 wk before the expected calving date $(\mathrm{kg} / \mathrm{d})$ & $1.9^{\mathrm{a}}(0.4)$ & $2.0^{\mathrm{a}}(0.3)$ & $2.0^{\mathrm{a}}(0.4)$ \\
\hline 305-d milk production $(\mathrm{kg})$ & $9,878^{\mathrm{a}}(1,422)$ & $9,930^{\mathrm{a}}(1,463)$ & $9,953^{\mathrm{a}}(1,262)$ \\
\hline $\begin{array}{l}\text { Reduction in milk production between } 16 \text { and } 12 \mathrm{wk} \\
\text { before the expected calving date }(\%)\end{array}$ & $33^{\mathrm{a}}(14.7)$ & $30^{\mathrm{a}}(10.4)$ & $29^{\mathrm{a}}(12.9)$ \\
\hline Parity & $2.1^{\mathrm{a}}(1.8)$ & $2.3^{\mathrm{a}}(1.4)$ & $2.1^{\mathrm{a}}(1.1)$ \\
\hline $\mathrm{BCS}$ & $2.9^{\mathrm{a}}(0.6)$ & $3.1^{\mathrm{a}}(0.7)$ & $2.9^{\mathrm{a}}(0.6)$ \\
\hline
\end{tabular}

${ }^{a-c}$ Means with different superscript letters within a row are significantly different $(P<0.05)$.

${ }^{1}$ In addition, the averages (SD in parentheses) of cow characteristics of the period before application of different dry period lengths are presented. 
Table 2. Pearson correlation coefficients ( $P$-values in parentheses) between cow characteristics of the period before application of different dry period lengths and total fat- and protein-corrected milk (from $60 \mathrm{~d}$ before expected calving date until $305 \mathrm{~d}$ in the subsequent lactation) yield $\left(\mathrm{FPCM}_{\text {total }}\right)$

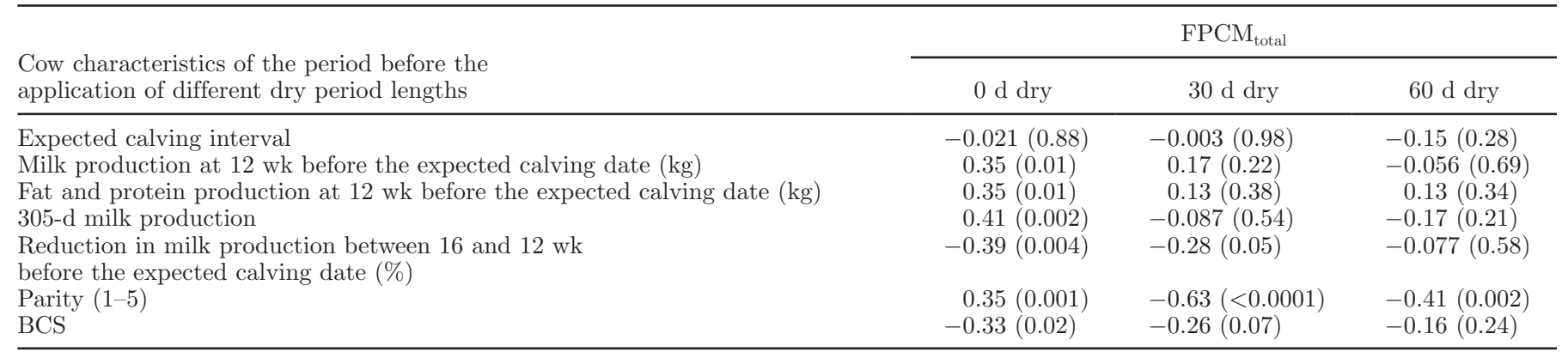

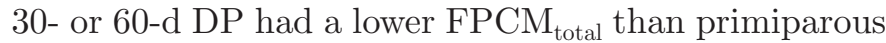
cows with a $30-$ or $60-d$ DP. Body condition score at 10 wk before the expected calving date $(\mathrm{r}=-0.33)$ and the reduction in milk production between 16 and 12 wk before the expected calving date $(\mathrm{r}=-0.39)$ were negatively correlated $(P<0.05)$ with $\mathrm{FPCM}_{\text {total }}$ for cows with no DP, whereas nonsignificant correlations were found for cows with 30- or 60-d DP.

Table 3 presents coefficient estimates of the final model for evaluating which cow characteristics were associated with production performance following the DP strategy. After backward elimination of variables, the following cow characteristics remained in the model: DP length, milk production at 12 wk before the expected calving date, parity, expected calving interval, and reduction in milk production between 16 and 12 wk before the expected calving date. In total, 4 interaction terms remained in the model. Figures 3, 4, and 5 present the effect of the significant interaction terms of cow characteristics (milk production at 12 wk before expected calving date, reduction in milk production between 16 and 12 wk before expected calving date, and parity) with DP length. Figure 3 presents the FP$\mathrm{CM}_{\text {total }}$ for cows with different parities and different DP lengths. No DP resulted for both primiparous cows and multiparous cows in the lowest $\mathrm{FPCM}_{\text {total }}$. The figure illustrates that the lowest loss in $\mathrm{FPCM}_{\text {total }}$ for cows with no DP was realized by multiparous cows, and the lowest production loss for cows with 30-d DP was realized by primiparous cows. Figure 4 presents $\mathrm{FPCM}_{\text {total }}$ for cows with different levels of milk production at $12 \mathrm{wk}$ before the expected calving date. The figure illustrates that the difference in $\mathrm{FPCM}_{\text {total }}$ between the $3 \mathrm{DP}$ groups was largest for cows with low milk production (e.g., 10 $\mathrm{kg} / \mathrm{d}$ ) at $12 \mathrm{wk}$ before the expected calving date. The lowest loss in $\mathrm{FPCM}_{\text {total }}$ was for cows with high milk production (e.g., $30 \mathrm{~kg} / \mathrm{d}$ ) at $12 \mathrm{wk}$ before the expected calving date. The FPCM $\mathrm{Ftal}_{\text {tol }}$ for cows with a milk production of $30 \mathrm{~kg} / \mathrm{d}$ at $12 \mathrm{wk}$ before the expected calving date and with a $60-\mathrm{d}$ DP was $10,444 \mathrm{~kg}$, whereas cows

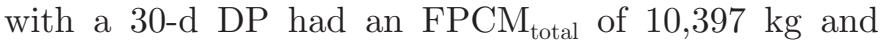
cows with no DP had an $\mathrm{FPCM}_{\text {total }}$ of 10,260 kg. Figure 5 presents $\mathrm{FPCM}_{\text {total }}$ for cows with different levels of reduction in milk production between 16 and $12 \mathrm{wk}$ before the expected calving date. The figure illustrates that the higher the reduction in milk production, the larger the difference in $\mathrm{FPCM}_{\text {total }}$ between the $3 \mathrm{DP}$ groups. This means that the lowest loss in $\mathrm{FPCM}_{\text {total }}$ for cows with $0 \mathrm{~d}$ DP was realized for cows with a small reduction in milk production between 16 and 12 wk before the expected calving date. The $\mathrm{FPCM}_{\text {total }}$ for cows with a reduction in milk production of $10 \%$ and with a $0-, 30-$, and $60-\mathrm{d}$ DP was $9,767,10,170$, and $10,432 \mathrm{~kg}$, respectively. The $\mathrm{FPCM}_{\text {total }}$ for cows with a reduction in milk production of $70 \%$ and with a $0-, 30-$, and $60-\mathrm{d}$ DP was 9,270, 9,960, and $10,400 \mathrm{~kg}$, respectively. So, the difference in $\mathrm{FPCM}_{\text {total }}$ between cows with no DP and $60-\mathrm{d}$ DP at a reduction in milk production between 16 and 12 wk of $10 \%$ was $665 \mathrm{~kg}$, whereas this difference was $1,138 \mathrm{~kg}$ at a reduction of $70 \%$.

\section{DISCUSSION}

Applying no DP resulted in the lowest $\mathrm{FPCM}_{\text {total }}$ compared with a 30- and 60-d DP, even for high-yielding and persistent-producing cows (Figures 4 and 5). Also, a 30-d DP resulted in a lower $\mathrm{FPCM}_{\text {total }}$ compared with a 60-d DP. Differences were however small, especially for high-yielding and persistent-producing cows. Also, Steeneveld et al. (2013) found that no DP resulted in the lowest milk production postcalving, even though especially high-producing cows were selected. That study did, however, not take into account the additional milk produced before calving due to a shorter DP. Klusmeyer et al. (2009) did take the additional milk production into account, and concluded that selecting high-producing cows at the time of drying off resulted in substantially greater total milk yield for cows with a 32-d DP compared with cows with a 60-d DP. Both studies (Klusmeyer et al., 2009; Steeneveld et al., 2013), 


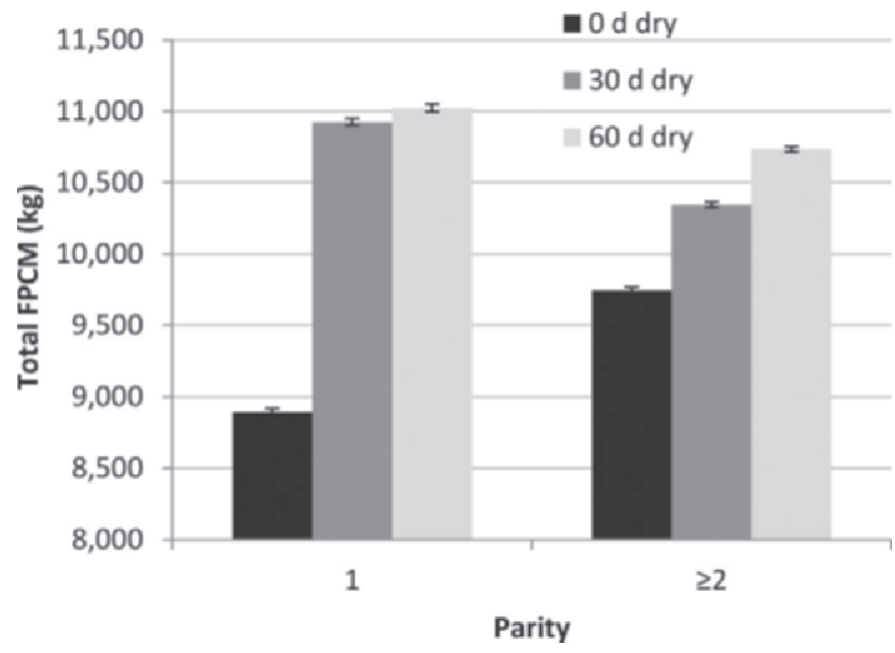

Figure 3. Estimated total fat- and protein-corrected milk (FPCM; from $60 \mathrm{~d}$ before the expected calving date until $305 \mathrm{~d}$ in the subsequent lactation) yield for cows of different parities and different dry period lengths. Values represent model predictions $(\mathrm{LSM} \pm \mathrm{SE}$ ).

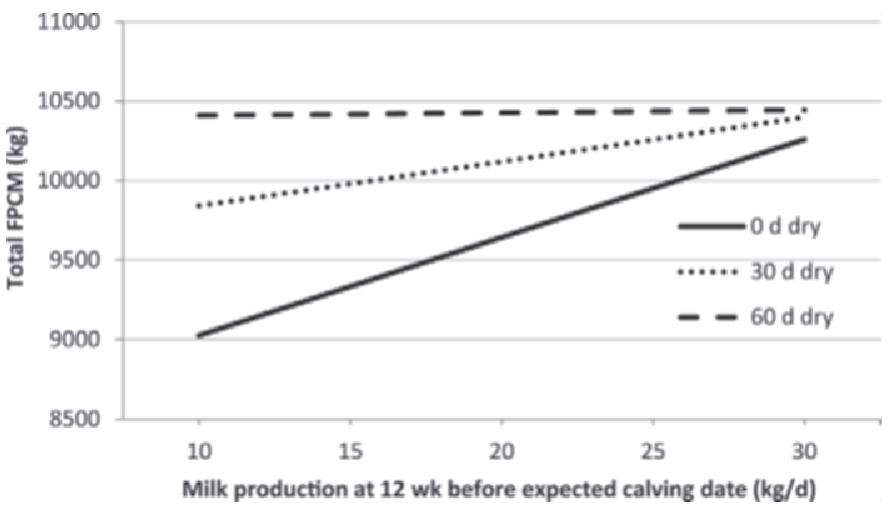

Figure 4. Estimated total fat- and protein-corrected milk (FPCM; from $60 \mathrm{~d}$ before the expected calving date until $305 \mathrm{~d}$ in the subsequent lactation) yield for cows with different milk production at 12 wk before the expected calving date and different dry period lengths. Values represent model predictions for a second-parity cow with a lipogenic ration, an expected calving interval of $400 \mathrm{~d}$, an expected calving season in October, and a reduction in milk production between 16 and $12 \mathrm{wk}$ before the expected calving date of $25 \%$.

Table 3. Coefficient estimates $(\beta)$ of the model for total fat- and protein-corrected milk (from $60 \mathrm{~d}$ before expected calving date until $305 \mathrm{~d}$ in the subsequent lactation) yield $\left(\mathrm{FPCM}_{\text {total }} ; \mathrm{kg}\right)$ for cows with no dry period (DP), a short DP, and a conventional DP length

\begin{tabular}{|c|c|c|c|}
\hline Variable & $\beta$ & $\mathrm{SE}$ & $P$-value \\
\hline Intercept & $10,888.5$ & 248.4 & \\
\hline DP length & & & $<0.0001$ \\
\hline $0 \mathrm{~d}$ & $-1,787.1$ & 152.5 & \\
\hline $30 \mathrm{~d}$ & -753.5 & 170.0 & \\
\hline $60 \mathrm{~d}$ & Referent & & \\
\hline \multicolumn{4}{|l|}{ Early lactation ration } \\
\hline Lipogenic & -15.3 & 17.1 & 0.37 \\
\hline Glucogenic & Referent & - & \\
\hline Milk production at $12 \mathrm{wk}$ before calving & 1.8 & 4.1 & 0.66 \\
\hline Parity & & & $<0.0001$ \\
\hline 1 & 289.7 & 33.5 & \\
\hline$\geq 2$ & Referent & - & \\
\hline Season & & & $<0.0001$ \\
\hline January-March & 910.9 & 25.1 & \\
\hline April-June & 377.2 & 28.7 & \\
\hline July-September & -61.7 & 23.6 & \\
\hline October-December & Referent & - & \\
\hline Expected calving interval (d) & -1.2 & 0.5 & 0.02 \\
\hline Reduction in milk production (\%) & -16.6 & 6.4 & 0.001 \\
\hline Interaction 1 & & & 0.007 \\
\hline Reduction in milk production $\times$ expected calving interval & 4.0 & 1.5 & \\
\hline Interaction 2 & & & $<0.0001$ \\
\hline Milk production at 12 wk before calving $\times 0$-d DP & 59.9 & 6.2 & \\
\hline Milk production at 12 wk before calving $\times 30-\mathrm{d}$ DP & 26.2 & 6.2 & \\
\hline Milk production at 12 wk before calving $\times 60$-d DP & Referent & - & \\
\hline Interaction 3 & & & $<0.001$ \\
\hline Reduction in milk production $(\%) \times 0$-d DP & -7.9 & 2.0 & \\
\hline Reduction in milk production $(\%) \times 30-\mathrm{d}$ DP & -3.0 & 2.5 & \\
\hline Reduction in milk production $(\%) \times 60-\mathrm{d}$ DP & Referent & - & \\
\hline Interaction 4 & & & $<0.0001$ \\
\hline Parity $1 \times 0$-d DP & $-1,146.0$ & 46.3 & \\
\hline Parity $1 \times 30-d \mathrm{DP}$ & 289.9 & 45.2 & \\
\hline Parity $1 \times 60-\mathrm{d}$ DP & 350.5 & 48.6 & \\
\hline Parity $\geq 2 \times 0$-d DP & -869.7 & 49.1 & \\
\hline Parity $\geq 2 \times 30-d$ DP & -409.7 & 45.3 & \\
\hline Parity $\geq 2 \times 60-\mathrm{d}$ DP & Referent & - & \\
\hline
\end{tabular}


however, were executed at commercial dairy farms and both studies did not take the effect of DP on milk components into account.

Although no DP and a 30-d DP resulted in the lowest $\mathrm{FPCM}_{\text {total }}$, the cow characteristics parity, daily milk production at $12 \mathrm{wk}$ before the expected calving date, and the reduction in daily milk production between 16 and 12 wk before the expected calving date can be used to select cows with limited production loss following no DP or a 30-d DP (Figures 3, 4, and 5). Multiparous cows have less production loss $(987 \mathrm{~kg})$ following no DP than primiparous cows $(2,132 \mathrm{~kg})$ and compared with a $60 \mathrm{~d}$ DP. Also, Annen et al. (2004) reported that multiparous cows have less production losses following no DP compared with primiparous cows. Primiparous cows are more suitable for a 30-d DP than multiparous cows, as primiparous cows have less production losses $(98 \mathrm{~kg})$ than multiparous cows $(389 \mathrm{~kg})$ and compared with cows with a $60 \mathrm{~d}$ DP (Figure 3), which is in contrast with previous results (Annen et al., 2004; Pezeshki et al., 2007). Especially cows with a high daily milk production at $12 \mathrm{wk}$ before the expected calving date and with a low reduction in milk production between 16 and $12 \mathrm{wk}$ before the expected calving date are most suitable for no DP or a short DP, as they have the greatest $\mathrm{FPCM}_{\text {total }}$ following no DP or a short DP (Figures 4 and 5). Cows with a daily milk production of $30 \mathrm{~kg}$ at $12 \mathrm{wk}$ before the expected calving date and with no DP have a reduction in $\mathrm{FPCM}_{\text {total }}$ of only 184 $\mathrm{kg}$ compared with cows with a daily milk production of $30 \mathrm{~kg}$ at $12 \mathrm{wk}$ before the expected calving date and with a $60-d$ DP.

Most studies focus on the lactation subsequent to the DP treatment (Gulay et al., 2003; Pezeshki et al., 2007; Watters et al., 2008), and only some studies investigated the additional prepartum production (Rastani et al., 2005; Mantovani et al., 2010; Schlamberger et al., 2010). In our study, the additional production $\left(\mathrm{FPCM}_{-60}\right)$ was considered a consequence of the DP and potentially of influence to the economic optimal DP length and was, therefore, taken into account. Including $\mathrm{FPCM}_{-60}$ has a large influence on the cow characteristics associated with limited loss in production. The daily milk production at $12 \mathrm{wk}$ before the expected calving date and the reduction in daily milk production between 16 and 12 wk before the expected calving date did have an effect on the $\mathrm{FPCM}_{\text {total }}$, but not on the $\mathrm{FPCM}_{305}$ (results not shown). This means that daily milk production at 12 wk before the expected calving date and reduction in daily milk production between 16 and 12 wk before the expected calving date influenced the $\mathrm{FPCM}_{-60}$. Also, parity and 305-d milk production from the previous lactation did have an effect on the $\mathrm{FPCM}_{305}$ (results not shown). Previously, it was reported that no interac-

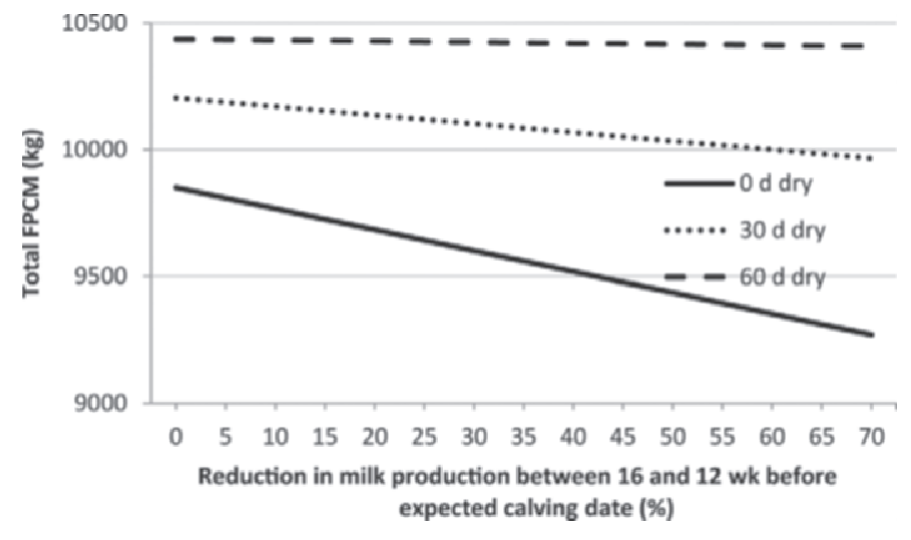

Figure 5. Estimated total fat- and protein-corrected milk (FPCM; from $60 \mathrm{~d}$ before the expected calving date until $305 \mathrm{~d}$ in the subsequent lactation) yield for cows with different reductions in milk production between 16 and 12 wk before the expected calving date and different dry period lengths. Values represent model predictions for a second-parity cow, with a lipogenic ration, an expected calving interval of $400 \mathrm{~d}$, an expected calving season in October, and a daily milk production at $12 \mathrm{wk}$ before the expected calving date of $20 \mathrm{~kg}$.

tion was found among a preplanned DP length $(4,7$, and $10 \mathrm{wk}$ ) and several cow characteristics (Sørensen and Enevoldsen, 1991). That study did, however, not include the additional production before calving, which possibly explains the difference from our results on finding interactions between DP length and cow characteristics.

It could be that different DP lengths cause different subsequent lactation lengths, for instance because of earlier ovulation (Gümen et al., 2005; de Feu et al., 2009). In our data set, however, the calving interval subsequent to different DP lengths was not different between the $\mathrm{DP}$ groups $(\mathrm{DP}=0 \mathrm{~d}$ : average calving interval of $397 \mathrm{~d}$; DP $=30 \mathrm{~d}$ : average calving interval of $405 \mathrm{~d}$; DP $=60 \mathrm{~d}$ : average calving interval of 408 $\mathrm{d} ; P=0.71)$. Also, the number of cows that did not reach 305 DIM $(n=60)$ and the number of cows with an early pregnancy $(\mathrm{n}=51)$ were similarly distributed over DP lengths (15 cows in the 0-d DP group, 17 cows in the 30-d DP group, and 19 cows in the 60-d DP group). Cows that did not reach the subsequent calving $(\mathrm{n}=28)$ had different reasons for not reaching that calving (not getting pregnant, udder problems, claw problems, or intentionally not inseminated). Reasons were similarly distributed over DP groups; for instance, intentionally not inseminated was for 6 cows in the 0 -d DP group, for 6 cows in the 30-d DP group, and for 2 cows in the 60-d DP group. The moment of culling of these cows was decided by the herd manager and the research leader, but the general rule was that cows will stay on the farm until 305 DIM as long as they gave at least $4 \mathrm{~kg}$ of milk/d. This means that culling of these cows was a result of the herd manager and research 
leader and that lactation length of these cows was not a result of DP length. Moreover, an analysis was performed with 101 cows that completed 305 DIM. The results were comparable with the analysis based on 161 cows. The same cow characteristics were significant and the magnitude of the effect was comparable. For these reasons, we could conclude that lactation length was not a result of DP length, and that it was, therefore, justified to estimate the milk yield for the cows. The lactation curve until 305 DIM was fitted and daily milk production until 305 DIM was summed up. The fit of the lactation curve was not different between 0-, 30-, and 60-d dry groups. Also, in previous research, the lactation curve of cows with no DP and a short DP was successfully fitted (Steeneveld et al., 2013) and the fit did not differ between DP lengths.

In several studies, the BCS was measured both before and after calving (e.g., Gulay et al., 2003; Andersen et al., 2005; Watters et al., 2008). In only one study was the BCS before calving associated with production postcalving (Sørensen and Enevoldsen, 1991) and reported not to be associated with the production performance postcalving. In the current study, BCS measured $10 \mathrm{wk}$ before the expected calving date did not have an effect on production performance in the multivariate analysis. A negative correlation was, however, found between the BCS 10 wk before the expected calving date and the $\mathrm{FPCM}_{\text {total }}$ for cows with $0 \mathrm{~d}$ dry (Table 2). This means that leaner cows before calving had a greater $\mathrm{FPCM}_{\text {total }}$ than fatter cows with no DP. Variation in BCS at wk 10 before the expected calving date was, however, small in this study, which could be related to limited effects of BCS precalving to production performance after a $30-$ or $60-\mathrm{d}$ DP. Moreover, BCS precalving was correlated with the expected calving date and the reduction in milk production between 16 and 12 wk before the expected calving date, which could have caused the BCS not to be included in the final model.

The reported cow characteristics can be included in a decision-support model to support the farmer on the economic optimal DP length for each individual cow. For a decision-support model on farm, only cow characteristics that are routinely available at the farm are useful. Moreover, cow characteristics should describe the cow at the moment a farmer has to decide about the DP length, which is in the period 3 to 2 mo before the expected calving date. Therefore, in our study, only cow characteristics were defined that are readily available and that describe the cow in the period 3 to 2 mo before the expected calving date. Ideally, a decision-support model will support the decision on the economic optimal DP length based on production and health characteristics (e.g., udder health) of the cow. Our study did, however, not take udder health characteristics of the cow into account. Therefore, additional research on the association between udder health at the moment of drying off and udder health in the subsequent lactation for different DP lengths is needed, including the influence of dry cow treatment. Moreover, current results are based on 1 research herd and before developing a final decision-support model, additional analyses must to be done based on data of several herds (and several consecutive years) to decide how applicable these results are across herds.

Based on current results, the difference in $\mathrm{FPCM}_{\text {total }}$ between a 30- and 60-d DP is small for cows with a relatively high daily production at 12 wk before the expected calving date. This would imply that especially the 30-d DP can be the economic optimal DP length for specific cows (e.g., multiparous cows with relatively high milk production at 12 wk before the expected calving date), especially when also other potential positive effects of a short DP are taken into account, such as a lower culling rate (Santschi et al., 2011a). Our results also show that no DP resulted in the lowest $\mathrm{FPCM}_{\text {total }}$ for all cows. This would imply that no DP will never be economically optimal for an individual cow when economic evaluation is based on milk revenues only. Potential positive consequences of no DP, such as an improved metabolic status (Rastani et al., 2005; Schlamberger et al., 2010), an earlier resumption of ovarian cyclicity postpartum (Gümen et al., 2005; de Feu et al., 2009), fewer days open (Gümen et al., 2005), and a lower replacement rate ( J. A. H. Heeren, Wageningen University, Wageningen, the Netherlands, personal communication) must, however, be included as well in a decision-support model. J. A. H. Heeren found that farms that switched completely to a no-DP management strategy had a reduced replacement rate compared with a conventional DP strategy. Based on these results, it was concluded that switching to no DP for all cows in the herd had a positive economic effect. Also applying a DP of $35 \mathrm{~d}$ for all cows in the herd was reported to be economically beneficial (Santschi et al., 2011b). It was, however, also reported that a DP of 7 wk was preferable under most circumstances (Sørensen et al., 1993). It has, however, not yet been investigated whether opting for no DP for an individual cow or applying an individual cow approach with different preplanned DP lengths within the same herd would be economically profitable.

\section{CONCLUSIONS}

Applying no DP and a 30-d DP resulted in the lowest FPCM $_{\text {total }}$ compared with a $60-d$ DP. The individual cow characteristics parity, daily milk production at 12 wk before the expected calving date, and reduction in 
daily milk production between 16 and 12 wk before the expected calving date predict the production performance of dairy cows with a 30-d DP or no DP. This implies that these cow characteristics can be used to select cows for specific DP lengths in a decision-support model to support the farmer on the economic optimal DP length for each individual cow.

\section{ACKNOWLEDGMENTS}

This research is financed by the Dutch Dairy Board (Zoetermeer, the Netherlands), the Dutch Product Board Animal Feed (Zoetermeer, the Netherlands), and CRV (Arnhem, the Netherlands).

\section{REFERENCES}

Andersen, J. B., T. G. Madsen, T. Larsen, K. L. Ingvartsen, and M. O. Nielsen. 2005. The effects of dry period versus continuous lactation on metabolic status and performance in periparturient cows. J. Dairy Sci. 88:3530-3541.

Annen, E. L., R. J. Collier, M. A. McGuire, J. L. Vicini, J. M. Ballam, and M. J. Lormore. 2004. Effect of modified dry period lengths and bovine somatotropin on yield and composition of milk from dairy cows. J. Dairy Sci. 87:3746-3761.

Butler, W. R. 2003. Energy balance relationships with follicular development, ovulation and fertility in postpartum dairy cows. Livest. Prod. Sci. 83:211-218.

Collard, B. L., P. J. Boettcher, J. C. M. Dekkers, D. Petitclerc, and L. R. Schaeffer. 2000. Relationships between energy balance and health traits of dairy cattle in early lactation. J. Dairy Sci. 83:2683-2690.

de Feu, M. A., A. C. O. Evans, P. Lonergan, and S. T. Butler. 2009. The effect of dry period duration and dietary energy density on milk production, bioenergetic status, and postpartum ovarian function in Holstein-Friesian dairy cows. J. Dairy Sci. 92:6011-6022.

Dohoo, I. R., S. W. Martin, and H. Stryhn. 2009. Veterinary Epidemiological Research. Atlantic Veterinary College Inc., Charlottetown, Prince Edward Island, Canada.

Grummer, R. R. 1993. Etiology of lipid-related metabolic disorders in periparturient dairy cows. J. Dairy Sci. 76:3882-3896.

Grummer, R.R., and R.R. Rastani. 2004. Why reevaluate dry period length? J. Dairy Sci. 87(E. Suppl.):E77-E85.

Gulay, M. S., M. J. Hayen, K. C. Bachman, T. Belloso, M. Liboni, and H. H. Head. 2003. Milk production and feed intake of Holstein cows given short (30-d) or normal (60-d) dry periods. J. Dairy Sci. 86:2030-2038.

Gümen, A., R. R. Rastani, R. R. Grummer, and M. C. Wiltbank 2005. Reduced dry periods and varying prepartum diets alter postpartum ovulation and reproductive measures. J. Dairy Sci. 88:2401-2411.

Klusmeyer, T. H., A. C. Fitzgerald, A. C. Fabellar, J. M. Ballam, R. A. Cady, and J. L. Vicini. 2009. Effect of recombinant bovine so- matotropin and a shortened or no dry period on the performance of lactating dairy cows. J. Dairy Sci. 92:5503-5511.

Mantovani, R., L. Marinelli, L. Bailoni, G. Gabai, and G. Bittante. 2010. Omission of dry period and effects on the subsequent lactation curve and on milk quality around calving in Italian Holstein cows. Ital. J. Anim. Sci. 9:101-108.

Pezeshki, A., J. Mehrzad, G. R. Ghorbani, H. R. Rahmani, R. J. Collier, and C. Burvenich. 2007. Effects of short dry periods on performance and metabolic status in Holstein dairy cows. J. Dairy Sci. 90:5531-5541.

Rastani, R. R., R. R. Grummer, S. J. Bertics, A. Gümen, M. C. Wiltbank, D. G. Mashek, and M. C. Schwab. 2005. Reducing dry period length to simplify feeding transition cows: Milk production, energy balance, and metabolic profiles. J. Dairy Sci. 88:1004-1014.

Santschi, D. E., D. M. Lefebvre, R. I. Cue, C. L. Girard, and D. Pellerin. 2011a. Complete-lactation milk and component yields following a short (35-d) or a conventional (60-d) dry period management strategy in commercial Holstein herds. J. Dairy Sci. 94:2302-2311.

Santschi, D. E., D. M. Lefebvre, R. I. Cue, C. L. Girard, and D. Pellerin. 2011b. Economic effect of short (35-d) compared with conventional (60-d) dry period management in commercial Canadian Holstein herds. J. Dairy Sci. 94:4734-4743.

Schlamberger, G., S. Wiedemann, E. Viturro, H. H. D. Meyer, and M. Kaske. 2010. Effects of continuous milking during the dry period or once daily milking in the first 4 weeks of lactation on metabolism and productivity of dairy cows. J. Dairy Sci. 93:2471-2485.

Sørensen, J. T., and C. Enevoldsen. 1991. Effect of dry period length on milk production in subsequent lactation. J. Dairy Sci. 74:1277-1283

Sørensen, J. T., C. Enevoldsen, and T. Kristensen. 1993. Effects of different dry period lengths on production and economy in the dairy herd- estimated by stochastic simulation. Livest. Prod. Sci. 33:77-90.

Steeneveld, W., Y. H. Schukken, A. T. M. van Knegsel, and H. Hogeveen. 2013. Effect of different dry period lengths on milk production and somatic cell count in subsequent lactations in commercial Dutch dairy herds. J. Dairy Sci. 96:2988-3001.

van Knegsel, A. T. M., G. J. Remmelink, S. Jorjong, V. Fievez, and B. Kemp. 2014. Effect of dry period length and dietary energy source on energy balance, milk yield and milk composition of dairy cows. J. Dairy Sci. 97:1499-1512.

van Knegsel, A. T. M., S. G. A. van der Drift, J. Čermáková, and B. Kemp. 2013. Effects of shortening the dry period of dairy cows on milk production, energy balance, health, and fertility: A systematic review. Vet. J. 198:707-713.

Watters, R. D., J. N. Guenther, A. E. Brickner, R. R. Rastani, P. M. Crump, P. W. Clark, and R. R. Grummer. 2008. Effects of dry period length on milk production and health of dairy cattle. J. Dairy Sci. 91:2595-2603.

Wildman, E. E., G. M. Jones, P. E. Wagner, R. L. Boman, H. F. Troutt Jr., and T. N. Lesch. 1982. A dairy cow body condition scoring system and its relationship to selected production characteristics. J. Dairy Sci. 65:495-501.

Wilmink, J. B. M. 1987. Adjustment of test-day milk, fat and protein yield for age, season and stage of lactation. Livest. Prod. Sci. $16: 335-348$ 